\title{
Study on the Transmission and Transformation of the Impurities in the Reductive Decomposition Process of Phosphogypsum
}

\author{
Bin Zhu ${ }^{1, a}$, Liping $\mathrm{Ma}^{1, \mathrm{~b}}$, Dalong Zheng ${ }^{1, \mathrm{c}}$, Guipeng $\mathrm{Ma}^{1, \mathrm{~d}}$, Yan Lian ${ }^{1, \mathrm{e}}$ and Jie \\ Yang ${ }^{1, f}$ \\ ${ }^{1}$ Faculty of Environmental Science and Engineering, Kunming University of Science and Technology, \\ Kunming 650500, China. \\ a765642082@qq.com, blipingma_kmust@163.com, c1151065990@qq.com, d690284579@qq.com, \\ 976748953@qq.com, ${ }^{\mathrm{f}} 785049493 @ q q . c o m$
}

Keywords: Phosphogypsum, reductive decomposition, simulation calculation, FactSage, silicon dioxide.

\begin{abstract}
To enrich the basic theory of the reductive decomposition process of PG(phosphogypsum), emphasis was laid on the exploration of the impact of the main impurities on the process. Firstly, the simulation computation was done on the systems of pure gypsum mixed with coal with or without impurities under nitrogen atmosphere, and the possible reactions in the process were deduced. Secondly, experiments were conducted in a TG-DTA integrated thermal gravimetric analyzer and a tube furnace. The slag and the flue gas from the experiments were characterized and analyzed to verify the accuracy of theoretical calculation. The results show that silicon dioxide can change the decomposition process of PG and finally transform to $\mathrm{Ca}_{3} \mathrm{SiO}_{5}$.
\end{abstract}

\section{Introduction}

Phosphogypsum (PG), which is composed primarily of calcium sulfate dehydrate, is a sort of industrial slags from the production of phosphoric acid. As an important source of calcium and sulfur, it can be applied in the production of chemical agents, construction materials and the amendment of soil[1-5].

Much work has been done by our group on the effective decomposition of PG. Different reductants have been used under different atmosphere with or without additives to explore the decomposition process of PG[6-11]. Even so, the basic theory still remains to be consummated.

\section{Simulation Calculation}

There are so many impurities in PG that it's difficult to list out all the reactions. The main reactions are shown below without consideration of the impurities:

$$
\begin{aligned}
& \mathrm{CaSO}=\mathrm{CaO}+\mathrm{SO}_{2} \uparrow+1 / 2 \mathrm{O}_{2} \uparrow \\
& \mathrm{C}+\mathrm{O}_{2}=\mathrm{CO}_{2} \\
& \mathrm{C}+\mathrm{CO}_{2}=2 \mathrm{CO} \\
& \mathrm{C}+1 / 2 \mathrm{O}_{2}=\mathrm{CO} \\
& \mathrm{CaSO}_{4}+1 / 2 \mathrm{C}=\mathrm{CaO}+\mathrm{SO}_{2}+1 / 2 \mathrm{CO}_{2} \\
& \mathrm{CaSO}_{4}+\mathrm{C}=\mathrm{CaO}+\mathrm{CO}+\mathrm{SO}_{2} \\
& \mathrm{CaSO}_{4}+3 / 2 \mathrm{C}=\mathrm{CaO}+\mathrm{S}+3 / 2 \mathrm{CO}_{2} \uparrow \\
& \mathrm{CaSO}_{4}+2 \mathrm{C}=\mathrm{CaS}+2 \mathrm{CO}_{2} \uparrow \\
& \mathrm{CaSO}_{4}+5 / 2 \mathrm{C}=\mathrm{CaS}+3 / 2 \mathrm{CO}_{2} \uparrow+\mathrm{CO} \uparrow \\
& \mathrm{CaSO}_{4}+4 \mathrm{C}=\mathrm{CaS}+4 \mathrm{CO} \uparrow \\
& \mathrm{CaSO}_{4}+\mathrm{CO}=\mathrm{CaO}+\mathrm{CO}_{2}+\mathrm{SO}_{2} \\
& \mathrm{CaSO}_{4}+4 \mathrm{CO}=\mathrm{CaS}+4 \mathrm{CO}_{2} \\
& \mathrm{~S}+\mathrm{O}_{2}=\mathrm{SO}_{2}
\end{aligned}
$$




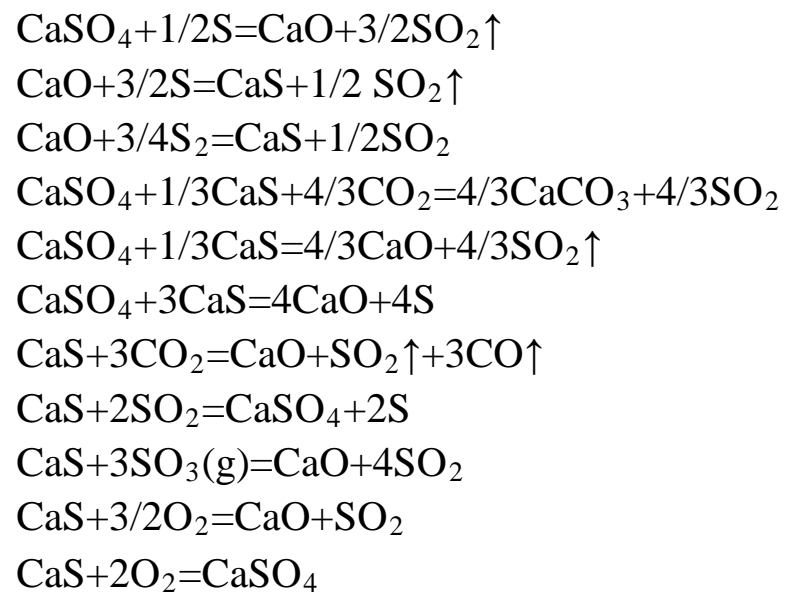

FactSage is one of the largest fully integrated database computing systems in chemical thermodynamics in the world. The Reaction Module and Equilib Module are used to deduce the possible reactions in one system in some condition. There are so many impurities like $\mathrm{SiO}_{2}, \mathrm{P}_{2} \mathrm{O}_{5}$, $\mathrm{Al}_{2} \mathrm{O}_{3}$ and $\mathrm{Fe}_{2} \mathrm{O}_{3}$ in $\mathrm{PG}$ among which $\mathrm{SiO}_{2}$ is the most. Thus in the next discussion only the impact of $\mathrm{SiO}_{2}$ on the reductive decomposition of $\mathrm{PG}$ is considered.

With the help of the Equilib Module, reaction (18), (25) (32) were deduced as the possible reactions in the systems of pure gypsum mixed with coal with or without $\mathrm{SiO}_{2}$ :

$$
\begin{aligned}
& \mathrm{CaSO}_{4}+3 / 2 \mathrm{C}=\mathrm{CaCO}_{3}+\mathrm{S}+1 / 2 \mathrm{CO}_{2} \uparrow \\
& \mathrm{CaCO}_{3}+1 / 8 \mathrm{~S}_{8}=3 / 4 \mathrm{CaS}+1 / 4 \mathrm{CaSO}_{4}+\mathrm{CO}_{2} \\
& \mathrm{CaSO}+1 / 3 \mathrm{CaS}=4 / 3 \mathrm{CaO}+4 / 3 \mathrm{SO}_{2} \uparrow \\
& \mathrm{CaS}+\mathrm{CO}_{2}=\mathrm{CaO}+\mathrm{CO}+1 / 2 \mathrm{~S}_{2} \\
& \mathrm{CaCO}_{3}+\mathrm{SiO}_{2}+\mathrm{S}=\mathrm{CaSiO} \mathrm{CaO}_{3}+\mathrm{CO}_{2} \uparrow+1 / 8 \mathrm{~S}_{8} \uparrow \\
& 2 \mathrm{CaCO}_{3}+2 \mathrm{SiO}_{2}+\mathrm{S}=2 \mathrm{CaSiO}_{3}+2 \mathrm{CO}_{2} \uparrow+1 / 8 \mathrm{~S}_{8} \uparrow \\
& \mathrm{CaSO}_{4}+\mathrm{CaS}+4 \mathrm{CaSiO}{ }_{3}+1 / 4 \mathrm{~S}_{8}=2 \mathrm{Ca}_{3} \mathrm{Si}_{2} \mathrm{O}_{7}+\mathrm{SO}_{2}+3 / 2 \mathrm{~S}_{2} \\
& 3 \mathrm{CaSO}_{4}+\mathrm{CaS}+4 \mathrm{Ca}_{3} \mathrm{Si}_{2} \mathrm{O}_{7}=8 \mathrm{Ca}_{2} \mathrm{SiO}_{4}+4 \mathrm{SO}_{2} \uparrow \\
& \mathrm{Ca}_{2} \mathrm{SiO}_{4}+\mathrm{CaO}=\mathrm{Ca}_{3} \mathrm{SiO}_{5}
\end{aligned}
$$

The Reaction Module is used to figure out some key parameters of the reactions involved in the decomposition process of phosphogypsum:

Table 1 The thermodynamic parameters of the reactions involved in the decomposition process of PG

\begin{tabular}{ccc||ccc}
\hline $\begin{array}{c}\text { Reactio } \\
\mathrm{n}\end{array}$ & $\begin{array}{c}\text { Reaction } \\
\text { Temperature } /{ }^{\circ} \mathrm{C}\end{array}$ & $\begin{array}{c}\text { Enthalpy } \\
\text { Change }\end{array}$ & $\begin{array}{c}\text { Reactio } \\
\mathrm{n}\end{array}$ & $\begin{array}{c}\text { Reaction } \\
\text { Temperature } /{ }^{\circ} \mathrm{C}\end{array}$ & $\begin{array}{c}\text { Enthalpy } \\
\text { Change }\end{array}$ \\
\hline$(1)$ & $\times$ & - & $(17)$ & $\times$ & - \\
$(2)$ & $\sqrt{ }$ & $<0$ & $(18)$ & $>1160$ & $>0$ \\
$(3)$ & $>710$ & $>0$ & $(19)$ & $\times$ & - \\
$(4)$ & $\sqrt{ }$ & $>0$ & $(20)$ & $\times$ & - \\
$(5)$ & $>830$ & $>0$ & $(21)$ & $<760$ & $<0$ \\
$(6)$ & $>800$ & $>0$ & $(23)$ & $\sqrt{ }$ & $<0$ \\
$(7)$ & $>470$ & $>0$ & $(24)$ & $\sqrt{ }$ & $<0$ \\
$(8)$ & $>200$ & $>0$ & $(25)$ & $\sqrt{ }$ & $>0$ \\
$(9)$ & $>300$ & $>0$ & $(26)$ & $>390$ & $>0$ \\
$(10)$ & $>450$ & $<0$ & $(27)$ & $\times$ & $>0$ \\
$(11)$ & $>890$ & $<0$ & $(29)$ & $>310$ & $>0$ \\
$(12)$ & $\sqrt{ }$ & $>0$ & $(30)$ & $>770$ & $>0$ \\
$(13)$ & $>1030$ & $>0\left(<440^{\circ} \mathrm{C}\right)$ & $(31)$ & $>970$ & $>0$ \\
$(14)$ & $\sqrt{ }$ & $<$ & $\left.>440^{\circ} \mathrm{C}\right)$ & & $>0$ \\
$(15)$ & $<0$ & $(32)$ & $>1300$ & $>0$ \\
$(16)$ & $\sqrt{ }$ & & & & \\
\hline
\end{tabular}


Remarks: The signal “ $\times$ ” represents the reaction can't proceed spontaneously from 0 to $1400{ }^{\circ} \mathrm{C}$; the signal “ $\sqrt{ }$ " represents the reaction can proceed spontaneously from 0 to $1400{ }^{\circ} \mathrm{C}$; the signal "-" means the value is no sense.

\section{Experiments}

The ultimate analysis of the coal used in the experiments is shown in Table 2. The particle size of coal is selected as $120 \sim 140$ mesh according to Zheng Shaocong[10].

Table 2 The ultimate analysis of coal

\begin{tabular}{cccccc}
\hline Compositions & $\mathrm{FC}_{\mathrm{d}} / \%$ & $\mathrm{~S}_{\mathrm{tad}} / \%$ & $\mathrm{M}_{\mathrm{ad}} / \%$ & $\mathrm{~A}_{\mathrm{d}} / \%$ & $\mathrm{~V}_{\mathrm{da}} / \%$ \\
\hline Contents (wt.\%) & 77.36 & 0.22 & 6.79 & 12.68 & 11.40 \\
\hline
\end{tabular}

To avoid the unnecessary interference from other impurities, pure gypsum is chosen as the raw material instead of PG. The proportion of gypsum and coal is 10:1, and the one of gypsum, coal and $\mathrm{SiO}_{2}$ is 10:1:1. Experiments were done in a TG-DTA integrated thermal gravimetric analyzer with a flow of nitrogen at $25 \mathrm{mg} / \mathrm{min}$ from room temperature to $1400{ }^{\circ} \mathrm{C}$ at $10{ }^{\circ} \mathrm{C} / \mathrm{min}$. The tube furnace experiments were carried out with a flow of nitrogen at $100 \mathrm{mg} / \mathrm{min}$ from room temperature to $1400{ }^{\circ} \mathrm{C}$ at $10{ }^{\circ} \mathrm{C} / \mathrm{min}$. The slag and the flue gas from the experiments were characterized and analyzed.

\section{Results and Discussion}

\subsection{The Reductive Decomposition of Pure Gypsum.}

As can be seen from Fig. 1 and Fig. 2, the mass loss and endothermic effect from $70{ }^{\circ} \mathrm{C}$ to $145{ }^{\circ} \mathrm{C}$ are due to the removal of the crystallization water of pure gypsum and the outer moisture of coal.

From 450 to $660{ }^{\circ} \mathrm{C}$, there was a mass loss and a exothermic process. The concentrations of $\mathrm{CO}$ and $\mathrm{CO}_{2}$ both increased as the temperature increased, while there was few $\mathrm{SO}_{2}$ produced. Thus it's likely that $\mathrm{CO}$ is generated via the pyrolysis of coal, and $\mathrm{CO}_{2}$ is yielded by reaction (7) (9), (25) and (26).

There was no obvious mass loss at the interval of 660 to $1000{ }^{\circ} \mathrm{C}$. In the flue gas, the concentration of $\mathrm{CO}$ decreased sharply while the one of $\mathrm{CO}_{2}$ stay at a high level. There was still few $\mathrm{SO}_{2}$ produced. As the mass loss of reaction (25) is tiny, it's possible that this reaction happens at this condition. The concentration decrease of $\mathrm{CO}$ is due to the cease of the pyrolysis of coal.

When the temperature was up to $1000{ }^{\circ} \mathrm{C}$, the concentration of $\mathrm{SO}_{2}$ rise until to the peak at 1080 . After that, it began to drop until to 0 at $1200{ }^{\circ} \mathrm{C}$. For it needs at least 27 minutes to evacuate the gases in the tube furnace, we can find that there wasn't $\mathrm{SO}_{2}$ generated above $1080{ }^{\circ} \mathrm{C}$. What's more, there wasn't obvious mass loss or sharp decrease of the $\mathrm{CO}_{2}$ concentration. So reaction (16) and (25) are the most likely reactions that may happen at this stage.

When the temperature was heated to $1170{ }^{\circ} \mathrm{C}$ or higher, big mass loss and endotherm could be seen. The endotherm effect at $1217{ }^{\circ} \mathrm{C}$ is caused by the polymorphism transformation of calcium sulfate which indicates that calcium sulfate doesn't all decomposed before $1217{ }^{\circ} \mathrm{C}$. In the flue gas, $\mathrm{CO}$ and $\mathrm{CO}_{2}$ were increasing while $\mathrm{SO}_{2}$ was also increasing but at a low level which stoped at $1280{ }^{\circ} \mathrm{C}$. The $\mathrm{XRD}$ pattern of the slag in Fig. 3 shows that the most decomposition product is $\mathrm{CaO}$ while $\mathrm{CaS}$ is also exist. It can be deduced from the phenomenon above that $\mathrm{CaO}$ is generated mainly by reaction (7), while CaS is by reaction (8) (10). 


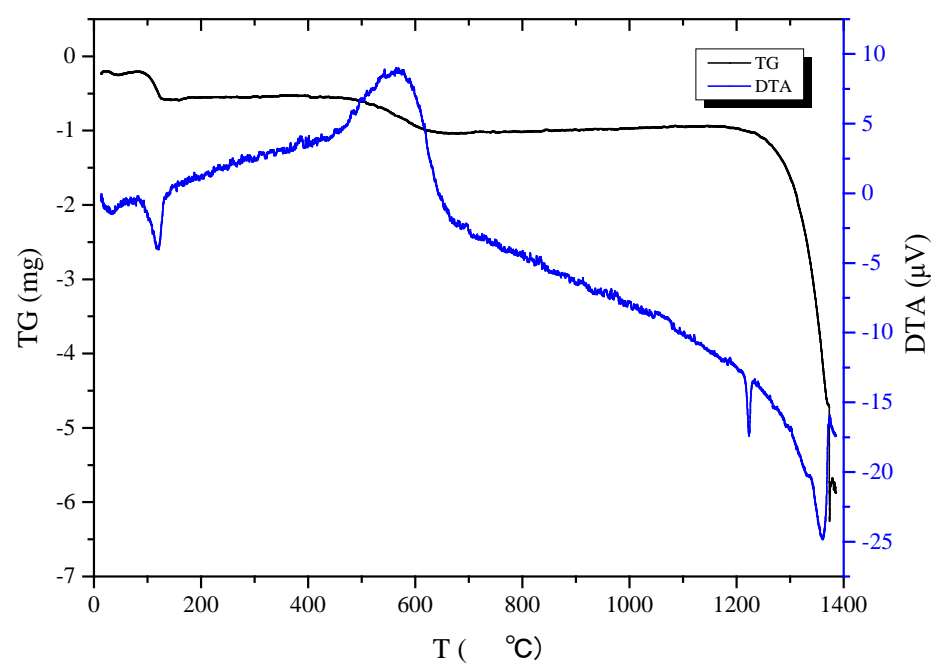

Fig. 1 The TG-DTA curves of gypsum mixed with coal under nitrogen atmosphere

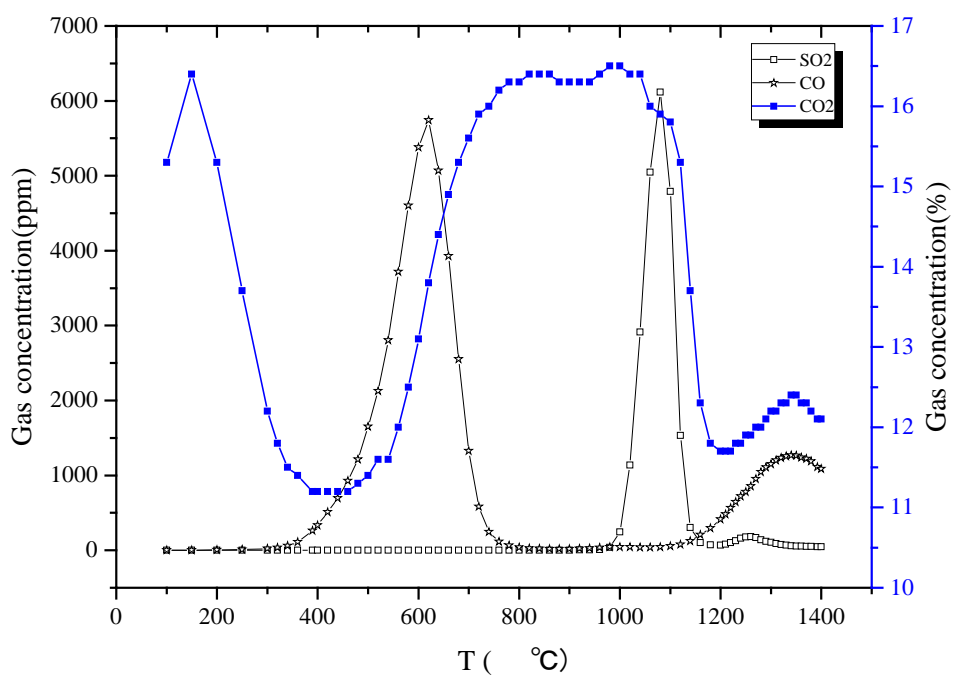

Fig. 2 The flue gas components of gypsum mixed with coal under nitrogen atmosphere

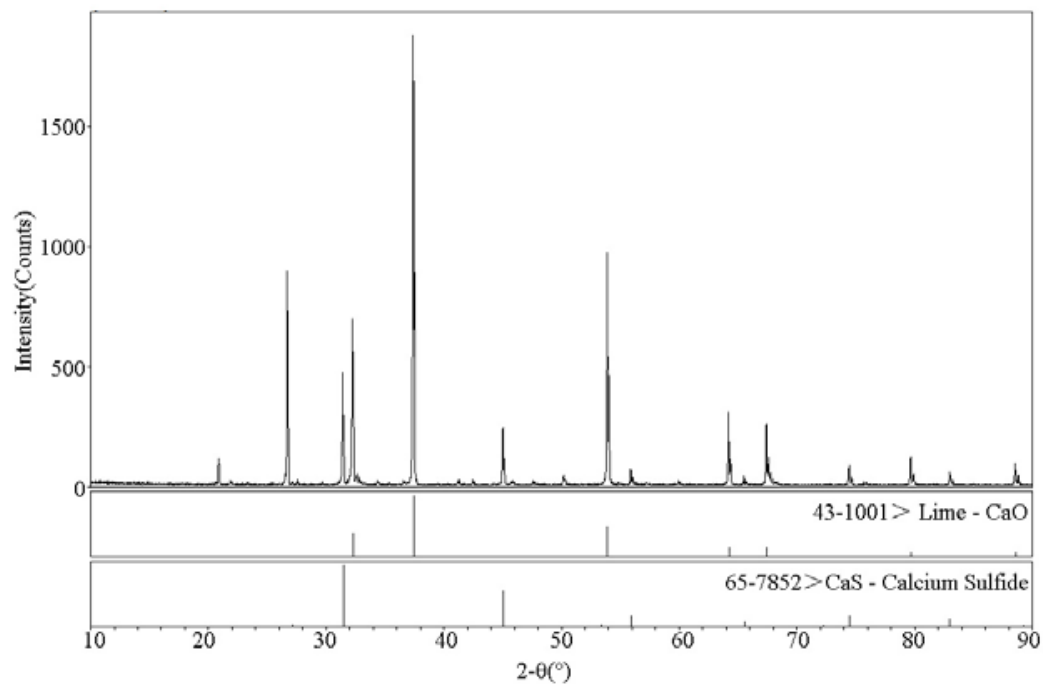

Fig. 3 The XRD pattern of the residue from the decomposition process of gypsum and coal under nitrogen atmosphere 


\subsection{The Impacts of $\mathrm{SiO}_{2}$ on the Decomposition of Pure Gypsum.}

As can be seen from Fig. 4 and Fig. 5, the changes of the system were very similar to that without $\mathrm{SiO}_{2}$ from 380 to $640{ }^{\circ} \mathrm{C}$. When the temperature was higher than $640{ }^{\circ} \mathrm{C}$ the concentration of $\mathrm{CO}$ decreased down to 0 at $720^{\circ} \mathrm{C}$, while the one of $\mathrm{CO}_{2}$ kept increasing and to a high value at $760 \sim$ $820{ }^{\circ} \mathrm{C}$. Thus it's likely reaction (25) is happening at the above interval.

Big mass loss could be observed from $1150{ }^{\circ} \mathrm{C}$, and it got alleviated above $1373{ }^{\circ} \mathrm{C}$. The endothermic peak at $1220{ }^{\circ} \mathrm{C}$ is still caused by the polymorphism transformation of calcium sulfate. Three more endothermic peaks appeared at 1319, 1347 and $1373{ }^{\circ} \mathrm{C}$. There wasn't any thermal effect except the above four. $\mathrm{SO}_{2}$ was generated above $1140{ }^{\circ} \mathrm{C}$, which was different from the situation without the addition of $\mathrm{SiO}_{2}$ in 4.1, and it kept increasing until to the peak value at $1333{ }^{\circ} \mathrm{C}$. At $1375{ }^{\circ} \mathrm{C}$, or 27 minutes later, there was few $\mathrm{SO}_{2}$ exist in the tube furnace. The concentration of $\mathrm{CO}$ and $\mathrm{CO}_{2}$ kept increasing from 1100 to $1375{ }^{\circ} \mathrm{C}$.

The XRD pattern of the slag in Fig. 6 shows that the main products are $\mathrm{Ca}_{3} \mathrm{SiO}_{5}$ and $\mathrm{Ca}_{2} \mathrm{SiO}_{4}$. There was also a little $\mathrm{CaSO}_{4}$ stay unreacted. $\mathrm{Ca}_{2} \mathrm{SiO}_{4}$ can be produced via reaction (31), while $\mathrm{Ca}_{3} \mathrm{SiO}_{5}$ can be generated by reaction (32). As there have mass loss and generation of $\mathrm{SO}_{2}$, reaction (31) can only happen from 1140 to $1333{ }^{\circ} \mathrm{C}$ according to the concentration change of $\mathrm{SO}_{2}$. When it's above $1373{ }^{\circ} \mathrm{C}$ where there are a little mass loss and no generation of $\mathrm{SO}_{2}$ and $\mathrm{CO}$, it's reaction (32) that cause the endothermic effect. The existence of reaction (31) and (32) should be based on the existence of reaction (28) or (29) and thus of $\mathrm{CaCO}_{3}$ and CaS. Therefore, reaction (25), (28) and (29) are likely to happen before reaction (31).

Among the reactions that can generate $\mathrm{SO}_{2}, \mathrm{CO}$ or $\mathrm{CO}_{2}$ from 1150 to $1319{ }^{\circ} \mathrm{C}$, only reaction (16) is a exothermic one of which the only solid reactant is $\mathrm{CaO}$ and the only gas product is $\mathrm{SO}_{2}$. There exists $\mathrm{CO}_{2}$ in the gas products in reaction (28) and (29), so there should be endothermic reactions with solid product $\mathrm{CaO}$ or gas product CO except reaction (16), (28) and (29). In view of this, reaction (7) and (10) are the most likely reactions from 1150 to $1319{ }^{\circ} \mathrm{C}$.

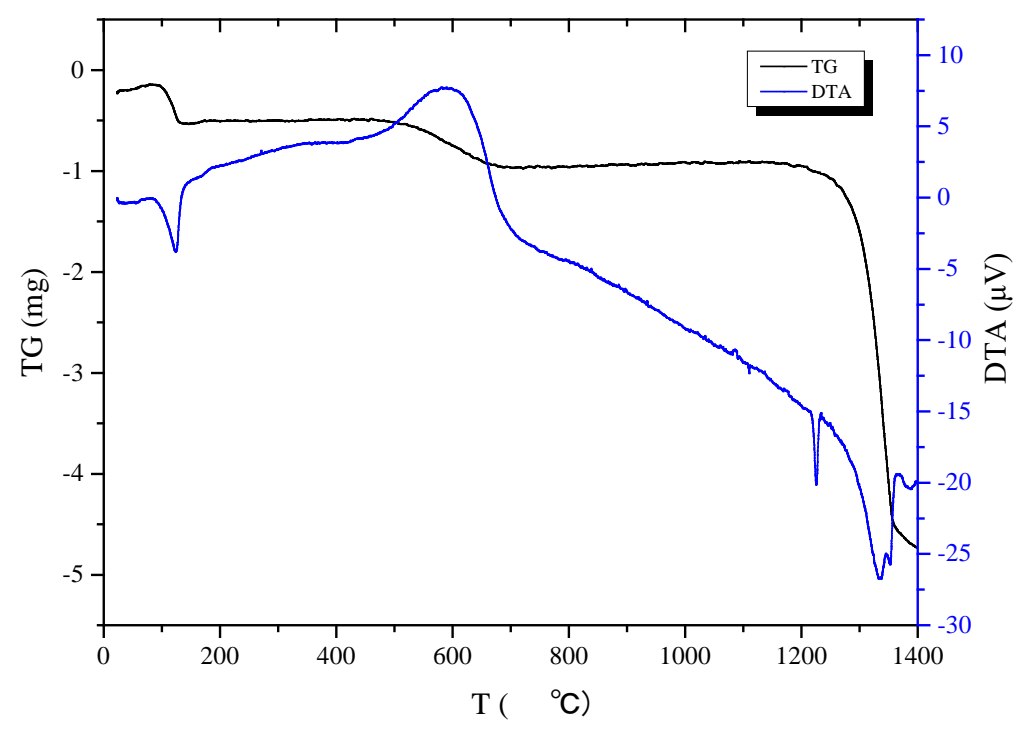

Fig. 4 The TG-DTA curves of gypsum and coal under nitrogen atmosphere with the addition of $\mathrm{SiO}_{2}$ 


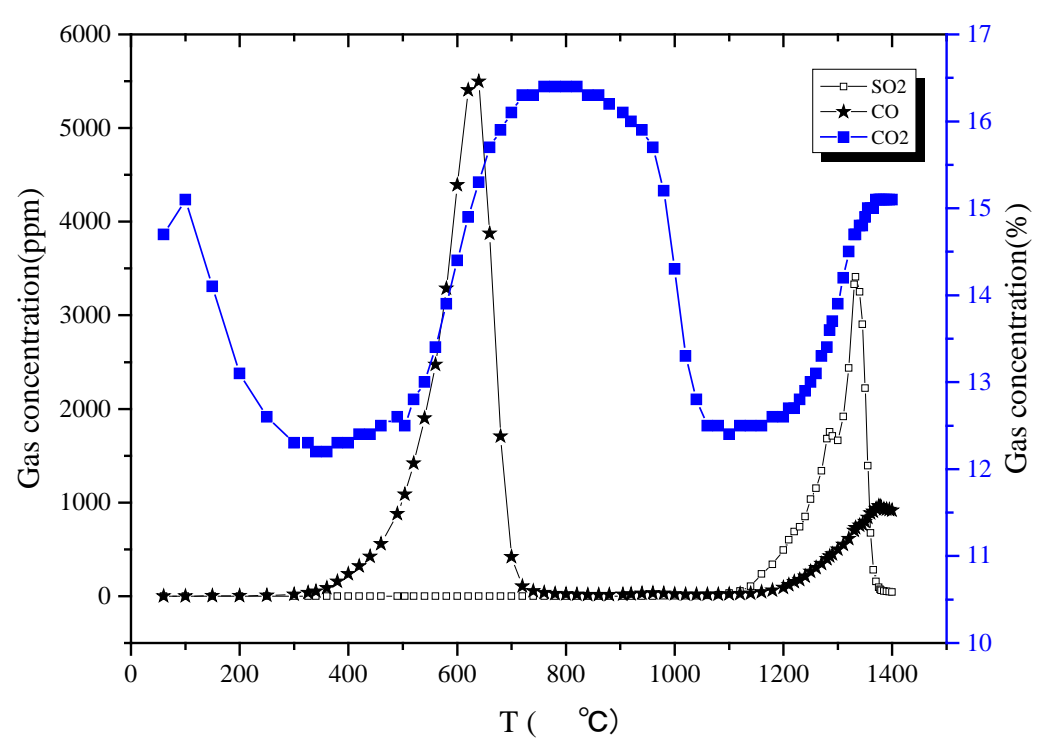

Fig. 5 The flue gas components of gypsum mixed with coal under nitrogen atmosphere with the addition of $\mathrm{SiO}_{2}$

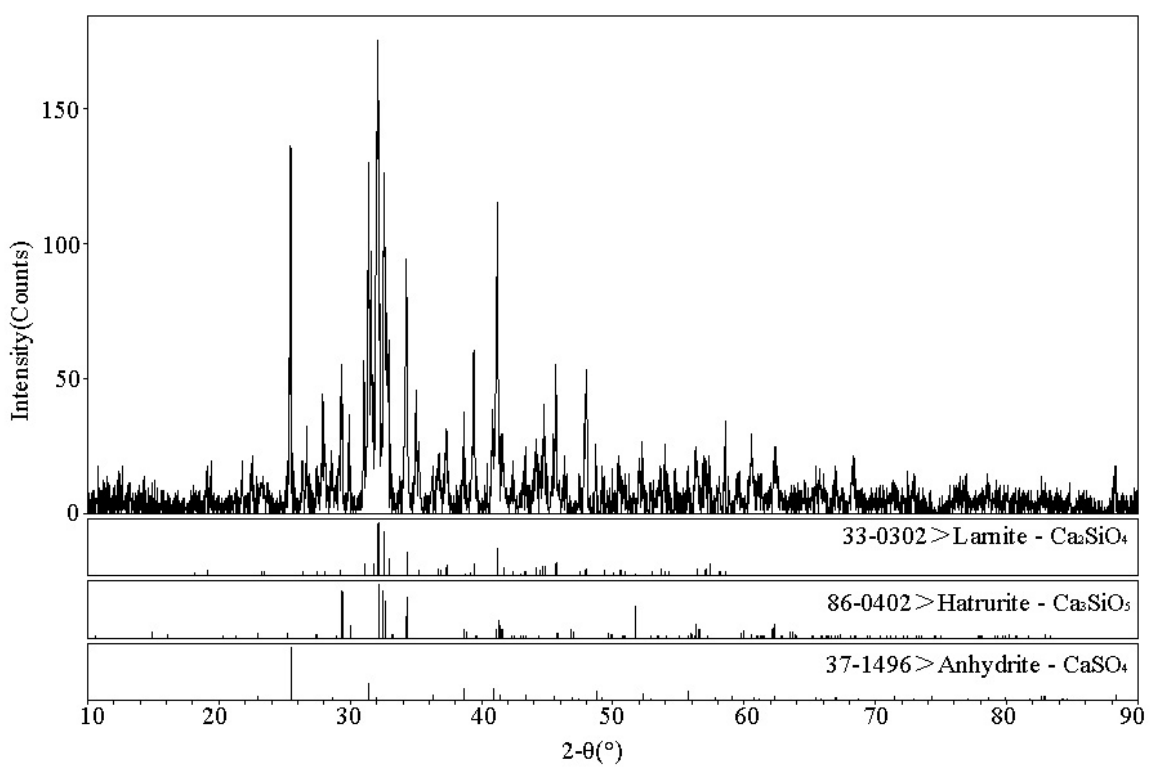

Fig. 6 The XRD pattern of the residue from the decomposition process of gypsum and coal under nitrogen atmosphere with the addition of $\mathrm{SiO}_{2}$

\section{Conclusion}

a) Most of $\mathrm{SO}_{2}$ in the gas products is generated via reaction (16). With the addition of $\mathrm{SiO}_{2}$, it will scramble for elemental sulfur via reaction (28) or (29) against reaction (16) which will lead to the lag of the large production of $\mathrm{SO}_{2}$.

b) $\mathrm{SiO}_{2}$ will change the decomposition route of $\mathrm{CaSO}_{4}$ and be transformed to $\mathrm{Ca}_{2} \mathrm{SiO}_{4}$ or $\mathrm{Ca}_{3} \mathrm{SiO}_{5}$, which is in good consistence with the theoretical results. 


\section{References}

[1]. Pérez-López R, Castillo J, Sarmiento A M, et al. Assessment of phosphogypsum impact on the salt-marshes of the Tinto river (SW Spain): Role of natural attenuation processes. Marine Pollution Bulletin. Vol. 62 (2011) No. 12, p. 2787-2796.

[2]. Singh M. Treating waste phosphogypsum for cement and plaster manufacture. Cement \& Concrete Research. Vol. 32 (2002) No. 7, p. 1033-1038.

[3]. Fang Z, Ning P, Yang Y, et al. Influence factors of deoxidizing phosphogypsum by compound reducing agent. Vol. 28 (2009) No. 3, p. 522-527.

[4]. Li H. Speed up the utilization of the industrial by-product gypsum in the 12th Five-Year Plan. China Chemical Industry News (2011-03-10).

[5]. Al-Hwaiti M S, Ranville J F, Ross P E. Bioavailability and mobility of trace metals in phosphogypsum from Aqaba and Eshidiya, Jordan. Chemie der Erde - Geochemistry. Vol. 70 (2010) No. 3, p. 283-291.

[6]. Ma L, Ning P, Zheng S, et al. Reaction Mechanism and Kinetic Analysis of the Decomposition of Phosphogypsum via a Solid-State Reaction. Industrial \& Engineering Chemistry Research. Vol. 49 (2010) No. 8, p. 3597-3602.

[7]. Ma L, Niu X, Hou J, et al. Reaction mechanism and influence factors analysis for calcium sulfide generation in the process of phosphogypsum decomposition. Thermochimica Acta. Vol. 526 (2011) No.s 1-2, p. 163-168.

[8]. Du Y, Ma L, Zheng S, et al. Effect of calcium chloride on the reductive decomposition of phosphogypsum with carbon monoxide. Journal of Anhui Agricultural Science. Vol. 38 (2010) No. 4, p. 1990-1991.

[9]. Zheng S, Ning P, Ma L, et al. Reaction properties of thermal decomposition of phosphogypsum in different atmospheres. Journal of Wuhan University of Technology (Transportation Science \& Engineering). Vol. 34 (2010) No. 3, p. 580-583.

[10]. Zheng S, Ning P, Ma L, et al. Reduction of phosphogypsum to sulfur dioxide with high sulfur coal. Chemical Enginerring. Vol. 38 (2010) No. 8, p. 35-38.

[11]. Yan B, Ma L, Xie L, et al. Reaction mechanism for iron catalyst in the process of phosphogypsum decomposition. Industrial \& Engineering Chemistry Research. Vol. 52 (2013) No. 49, p. 17383-17389. 